design, and here we find that it is not a function of power alone but of maintaining power at height by boost. Various boosts have been introduced on engines varying between the two-stage, two-speed blower, to the exhaust-driven turbine type.

I suggest that the future economical cruising stratum will be in the neighbourhood of $35,000 \mathrm{ft}$. If that is to be the right level then passengers cannot be asked to put up with the barometer at less than 6 in., so that pressurized cabins suitably heated and pressed will become the standard order of the commercial machine.

Long-range bombers have drifted into the fourengined type of great reliability with speeds up to 300 m.p.h., but they are voracious petrol eaters. Single-seater fighters with engines of 2,000 horsepower with wings not too heavily loaded, so that manœuvrability is not impaired, exceed the 400 m.p.h. mark. That is where we are to-day.

How all this is to be exploited for the benefit of inter-communication afterwards is difficult at present to say, and it is not clear how loads can in fact yet pay. We have perhaps come to the definite end of a type again, and it is not certain whether the tractor will eventually survive against the pusher, or whether present power units, with their big disk area propellers, are the end of the story. Aeronautics is now a science and development will not stop. There are great possibilities looming ahead, revolutionary in character ; but the present situation may be prolonged by a great increase in wing loading with assisted take off.

Here is a brief résumé of the results of those first experiments by the Wrights. (Mr. Orville Wright celebrated his seventieth birthday on August 19. See Nature of August 16, p. 191.) It is indeed the duty of man to see that what the Wrights first introduced-one of the greatest inventions and contributions to mechanical science-is eventually used for the benefit of the world and not for the destruction of civilization. We cannot blame the Wright brothers for the prostitution of their invention that has taken place. Those of us who knew the two brothers will always cherish affection for them and the memory of two remarkably quiet, charming people. It will be for succeeding generations to prove that they introduced into the world, not a curse, but a means of transport which will eventually bind nations together on a basis of mutual understanding and goodwill.

\title{
CROP DAMAGE BY AIR ATTACK
}

\author{
By Sir John Russell, F.R.S. \\ Rothamsted Experimental Station
}

$\mathrm{T}$ WO possibilities of damage to crops by enemy action are now so near that warnings have been issued along with instructions showing what is to be done should the necessity for action arise. The Ministries of Home Security and of Agriculture have sent out to farmers three leaflets giving simple but precise methods for coping with attempts to destroy our crops either by fire or by poison gas.

In regard to fire, the problem is an old one in Australia and in Canada, so that a certain amount of experience is already available. In both countries the prairie or bush regions are liable to become very dry during periods of drought, and a spark or even a cigarette end may start a conflagration that races over miles of country, causing havoc wherever it goes. I shall never forget the Australian bush fires in the summer of 1938-39 (December and January); they were impressive beyond words, and one marvelled at the skill and courage of the Australians in facing up to what seemed irresistible devastation, gradually limiting and finally subduing it. In Great Britain experience is far more limiter, and except for occasional fires started by picnickers or campers in young forestry plantations, the only fires ever. seen in British fields are those caused by sparks from railway engines. But, small as it is, this experience is invaluable at the present time, and has clearly been drawn upon in the preparation of these pamphlets.

The reason so few field or forest fires are seen in Great Britain is, of course, the unsuitability of the climate. Occasionally, it is true, we get a summer where crops and grass dry up and look as if they would burn easily. 1940 was an example, and it is fortunate for us that the Germans made no large-scale attacks then. 1941 has been much wetter, and nothing could have fired the crops this summer. In spite of this, however, the Ministries are taking no risks, and are issuing instructions should the case arise.

Greenleaf crops are obviously exempt from risk, and the only danger might come to cereals. Oats are usually cut before they are dead ripe, and they normally still contain so much sap as to be noncombustible ; no danger arises from railway-engine sparks, and it may be assumed that incendiary 
leaves or bombs would be harmless. Wheat is left longer and dries out more: it does not usually, however, become dry enough to burn easily, and railway-engine sparks rarely set a wheat field on fire. Barley, however, is generally left until it is dead ripe, and becomes drier than any other of the cereals, hence it is most likely to catch fire. Even so, barley fires are not very common, considering the number of barley fields in the country, and the total loss of standing corn is not great. As barley fields are scattered in among oat, root and grass fields, the danger of spreading, even if a fire should start, is only small.

The most serious risk is on the stubbles, if very dry weather should set in after the harvest. The short residual straw easily dries sufficiently to become inflammable, and if a fire starts it creeps over the field. There is no harm in that, so long as the fire keeps to the stubble; even some good may result if the heat is sufficient to kill insects and their eggs, and to destroy fungi and weed seeds ; also the heating of the soil liberates plant food. But if sheaves of corn are still standing out, or if a stack of corn or of hay has been built up in the field, then there is danger that it may be set on fire.

Fortunately, Australian and Canadian experience shows how to give protection: the stubble should be ploughed up as speedily as possible, or if that be impracticable, then strips must be ploughed so as to divide the field into compartments; if a fire starts in one of them it can go no farther. Stacks must be well isolated from each other and from the stubble; they are best put in grass or root fields, but if they must be in a cereal field they should be surrounded by a belt of ploughed land.

Hedges also are liable to catch fire, especially if they contain much dry material at the bottom, as not infrequently happens. The precaution here is to keep the hedge well cut back and well cleaned.

In view of the fact that most of our grain is grown in the dry parts of England, the amount of water available for putting out a fire may not be great. Methods are indicated in the leaflets for organizing water supplies, and making such arrangements as are possible beforehand for facilitating action when the fire comes. Beating is effective, and although many parts of the country-side are familiar enough with the simple form of this operation that suffices for dealing with gorse and heather fires, a serious field fire would need more elaborate precautions, and these are duly described.

This fire danger has attracted the attention of a number of the farmers' organizations. The Hampshire Branch of the National Farmers' Union bas issued recommendations which include such important details as the cutting and ploughing up of fire breaks through standing crops across the direction of the prevailing wind, but emphasizes the need for organizing groups of fire watchers and helpers, since the first minutes are always the most important.

The danger from gas is more oppressive because it lies right outside the countryman's experience, and every untested danger seems terrifying until it has actually come. It might not come at all, and if it does, it might prove relatively harmless. Certainly, the bombs that caused so much fear in the country-side before they arrived were treated with scant respect once it was seen how little damage they do in a field : a hole that is quickly filled in, or a fence that is soon mended, and all signs are removed. Many farm-workers have spoken contemptuously of the bombs: "They didn't even kill a rabbit" was a common phrase, and there was great relief at finding that the much-vaunted terror had so little substance. There is, of course, a world of difference between an open field and a crowded city.

It is possible that gas bombs in the fields would be equally innocuous, but the Ministry has set out instructions as to what should be done if they come. As the instructions cannot cover every possible case, the first and chief one is to get in touch promptly with the gas identification officer of the local authority.

Only persistent gases are considered likely to do serious harm, and of these the blister gases are the most important, especially mustard gas; but it is stated that still further caution would be needed against lewisite, on account of the risk of arsenic poisoning. Two modes of distribution are dealt with : by bombs and by spraying; bombs cause intensive contamination over a small area, and spraying a less intense contamination over a larger area. The crops become discoloured or scorched in appearance, and some of the liquid may remain either on the plant or on the soil ; mustard gas has a faint, rather onion-like smell, while lewisite sometimes, but not always, has a smell of geraniums. The instructions to the farmer are quite simple: he must keep human beings and animals out of the affected areas, and get in touch with the local A.R.P. authorities, who will presumably have access to experts able to give fuller advice. Visibly damaged crops should not be fed to animals, though if grain crops survive and continue to grow, the expert might advise that they could be used as seed.

Stored crops usually present less difficulty. The usual protective agents, clamps, thatch, barns, and tarpaulins are said to be adequate against blister gas, and nothing more than prolonged airing is needed to overcome the trouble. Concrete silos 
give complete protection, so long as the top is closed, but wire and paper silos may not always prove adequate, and a certain amount of dismantling and cutting out may have to be done. Stack or clamp silos afford no protection, and any part that has been splashed or sprayed must be removed and destroyed. Running water is safe, and need cause no anxiety, but water in shallow ponds or storage tanks, if contaminated with blister gas, may remain dangerous for long periods.

Naturally, one hopes that these particular dangers may never arise, but it is comforting to realize that if they should the Ministries of Agriculture and Home Security are alive to the possibilities, and that farmers have been forewarned and advised as to what steps they should take.

\title{
DRUG PLANTS NATIVE TO GREAT BRITAIN
}

\author{
By Dr. W. O. James \\ Botany Department, University of Oxford
}

$\mathrm{A}^{\mathrm{s}}$ PART from herbalist simples, there are some half-dozen or so ${ }^{i}$ plants of Europe and the British Isles which yield drugs of first-class medical importance. The annual consumption of Great Britain runs into hundreds of tons of crude dried material, almost the whole of which normally comes from the Continent, particularly from Belgium, Germany, the U.S.S.R. and the Balkans. Consumption is not limited to the requirements of the people of Great Britain. A re-export trade of refined drugs exists on a considerable scale and, since this largely goes to the western hemisphere, and is economical in its demands on cargo space, there is point in trying to keep it alive at the present time.

First, however, must come home needs. The Ministry of Health has issued several pronouncements stressing "the importance and urgency of the question of supply and, through its Vegetable Drugs Committee, has reviewed the situation and made certain cautious recommendations.

Serious shortage already exists of some of the drugs in question, a situation which had its parallel in the War of 1914-18. The steps taken then were only partially successful, but should af :ord some useful background of experience now, though it is too early yet to say whether the implied lessons have been learnt.

The steps open to us include collection of wild plants and increased cultivation. Each is very narrowly restricted both by botanical and economic causes and will require skilful and determined handling if anything useful is to be achieved. The Ministry of Health has ruled that war-time production must remain on a commercial basis. Strictly speaking, this is impossible. It is true that the produce is being handled through the usual trade channels, but collection depends upon volunteers who can receive nothing commensurate with any normal valuation of their time and labour. This end of the effort is essentially a gift to the country - a commendable if indirect warservice-and should be recognized as such. It is being undertaken by women's institutes, women's voluntary services, boy scouts, girl guides and some schools.

Government assistance has not been lacking. The Ministry of Health has sought to give a lead, and has provided machinery for co-ordination and advice. In hard cash, grants have been given to certain famous and well-established firms to enable them to extend their drying-plant and, on a smaller scale, to the Oxford Medicinal Plants Scheme, which has been called into existence to make selections from the native wild plants, combining trials with a limited scale of present production.

It has been officially recommended by the Ministry of Health and the Medical Research Council that effort be concentrated on belladonna, colchicum, foxglove, male fern, henbane, sphagnum, stramonium, dandelion-root and valerian, with special emphasis on the four italicized. This recommendation does not seem to have received all the attention it deserves. Besides these plants of well-established therapeutic value, the flora of Great Britain contains many more which are normal articles of the drug trade, but the value of which no responsible medical man would put in the same category. Bluntly speaking, nobody is going to die prematurely or suffer great pain for lack of them, as many might suffer or die for lack of belladonna or foxglove. By no efiort of the will can the harvesting of such inessentials be made to appear a significant contribution to the war effort. Nevertheless, judging from the inquiries and literature I have received, there seems to be a real danger of anxious and willing help 